\title{
MELANOMA KONJUNGTIVA
}

\author{
Josefien M. Saerang \\ Laya M. Rares
}

\begin{abstract}
Bagian Ilmu Kesehatan Mata Fakultas Kedokteran Universitas Sam Ratulangi Manado
Email: layarares@yahoo.com
\end{abstract}

\begin{abstract}
Conjunctival melanoma is a very rare tumor of the eye which can be fatal. We reported a 42-year-old female having had a black tumor in her right eye for 6 months before she was admitted to the hospital. This tumor was neither painful, itchy, nor bleeding. The tumor was derived from a nevus. Vision of the right eye was $6 / 15$, corrected with $\mathrm{C}=100 \times 105^{\circ}(6 / 9)$ and vision of the left eye was $6 / 6$. The field of vision of the right eye was limited to the lateral part; color vision test was normal; Amsler grid test was normal; pupils were isocor; and Relative Afferent Papillary Defect (RAPD) was negative. Movements of the right eye ball were normal, except for the right temporal part due to the tumor. The anterior segment of the right eye was normal. A funduscopy examination of the right eye showed that the optic papilla, retina, and macula were within normal limits. Routine blood examination, liver function, kidney function, lipid profile, clotting time, and bleeding time were within normal limits. ECG was within normal limits, and a chest X-ray showed no metastase. Based on all examinations, this patient was diagnosed as having conjunctival melanoma, associated with simple hypermetropic astigmatisme, and presbyopia.
\end{abstract}

Keywords: melanoma, tumor

\begin{abstract}
Abstrak: Melanoma konjungtiva merupakan jenis tumor yang sangat jarang dan dapat berakibat fatal. Kami melaporkan seorang wanita berusia 42 tahun, datang ke poliklinik mata dengan keluhan benjolan berwarna hitam di mata kanan sejak 6 bulan sebelum dirawat di rumah sakit. Benjolan tidak nyeri, tidak gatal dan tidak berdarah. Benjolan berasal dari nevus yang tumbuh semakin besar. Visus okuli dekstra (VOD) 6/15 yang dapat dikoreksi dengan kacamata $\mathrm{C}+100 \mathrm{X} 105^{\circ}$ menjadi 6/9 dan visus okuli sinistra (VOS) 6/6. Lapangan pandang okuli dekstra terbatas di lateral kanan, tes color vision dan amsler grid normal, pupil isokor, Relative Afferent Papillary Defect (RAPD) negatif. Gerakan bolamata masih dalam batas normal ke segala arah kecuali ke temporal kanan agak terhalang karena adanya tumor. Segmen anterior okuli sinistra dalam batas normal. Pada funduskopi okuli dekstra dan sinistra: papil nervus optikus, retina dan makula dalam batas normal. Laboratorium darah rutin, fungsi hati, ginjal, profil lipid, clotting time dan bleeding time dalam batas normal. Pemeriksaan EKG dalam batas normal dan X-foto toraks tidak terdapat metastase. Pasien didiagnosis melanoma konjungtiva yang disertai astigmatisma hipermetropikus simpleks OD dan presbiopia.
\end{abstract}

Kata kunci: melanoma, tumor

Melanoma konjungtiva merupakan tumor yang jarang sekali terjadi yaitu hanya satu dalam selang waktu 40 tahun, sama halnya dengan melanoma koroid, dan sekitar 500 kali lebih kurang dari melanoma kulit. Insidensnya berkisar $0,2-0,8$ per juta populasi kulit putih. ${ }^{1-4}$ Melanoma konjungtiva berpotensi sebagai neoplasma yang mematikan, dengan tingkat kematian rata-rata 10 tahun sekitar 30\%. ${ }^{1}$ Tumor ini diidentifikasi paling sering di daerah perilimbal interpalpebra konjungtiva bulbi. Tumor yang berlo- 
kasi di konjungtiva palpebra, forniks, karunkel, plika semilunaris atau margo palpebra memiliki prognosis buruk untuk kelangsungan hidup. ${ }^{1,5}$ Melanoma konjungtiva tidak memiliki predileksi jenis kelamin dan ditemukan pada dewasa dan usia pertengahan. Walaupun jarang, kasus ini pernah dilaporkan pada anak-anak. ${ }^{6}$ Jenis melanoma ini terutama dijumpai pada populasi kulit putih, dan jarang pada populasi kulit hitam atau bukan kulit putih. Penelitian terakhir melaporkan bahwa seperti halnya melanoma kutaneus, dewasa ini insidens melanoma konjungtiva juga meningkat. ${ }^{3,4,7}$

Oleh karena adanya variasi histologik, maka World Health Organization (WHO) mengusulkan untuk lesi ini primary acquired melanosis (PAM) dengan atau tanpa atipia. $^{8-11}$

\section{FREKUENSI, ANGKA KESAKITAN DAN ANGKA KEMATIAN}

Di Amerika Serikat melanoma konjungtiva maligna primer lebih kurang umum dibandingkan melanoma kutis. Melanoma konjungtiva maligna tercatat hanya $2 \%$ dari keseluruhan keganasan okuler. Insidens PAM dengan atipia atau dengan melanoma konjungtiva maligna diperkirakan 0,052 kasus per tahun per 100.000 populasi di Denmark. ${ }^{8}$ Di Swedia, hanya dua kasus melanoma konjungtiva maligna primer didiagnosis pada tahun 1987; kejadian rata-rata dari melanoma konjungtiva adalah 0,74 kasus per satu juta penduduk pria dan 0,54 kasus per satu juta penduduk wanita. Insiden melanoma konjungtiva meningkat di Swedia dari tahun 1960-2005. ${ }^{8}$

Keseluruhan angka kematian terkait dengan tumor melanoma konjungtiva adalah 25-26\%. Ratio ini meningkat sampai 40$44 \%$ bila tumor muncul dari PAM dengan pola pertumbuhan intraepitelial pagetoid. Tumor ini cenderung meluas ke kelenjar limf regional parotis, preaurikular, submandibular atau servikal.

Ketebalan tumor, jenis mixed cell dan invasi ke limfatik yang ditemukan pada pemeriksaan histologik meningkatkan ratio kematian (3-4 kali). Jacobiec et al menge- mukakan beberapa kondisi dengan gambaran prognosis jelek: tumor di lokasi yang sulit (karunkel, konjungtiva palpebra, atau konjungtiva forniks), atipik sedang sampai berat, invasi lebih dalam ke jaringan okuler, lebih dari lima gambaran mitosis per 10 lapangan pandang, dan kurangnya respon inflamasi akibat tumor. ${ }^{8}$

\section{LAPORAN KASUS}

Seorang wanita berusia 42 tahun, suku Kotamobagu, datang ke poliklinik mata dengan keluhan utama adanya benjolan warna hitam di mata kanan sejak 6 bulan sebelum masuk RS (Gambar 1). Benjolan tidak nyeri, tidak gatal dan tidak berdarah. Benjolan berasal dari tahi lalat yang tumbuh semakin besar, lokasinya di sebelah temporal limbus oluli dekstra (OD). Tahi lalat timbul sejak masih remaja, awalnya hanya berupa titik hitam. Makin lama titik hitam ini mulai melebar ke atas dan ke bawah, dan terlihat seperti kulit yang keriput. Sejak enam bulan terakhir ini tahi lalat mulai tumbuh keluar mata, dan berukuran seperti kacang polong. Pasien sering merasa matanya kering sehingga selalu memakai tetes mata Insto. Ia tidak pernah memeriksakan matanya ke dokter karena hal itu dianggap biasa-biasa saja. Riwayat keluarga: dalam keluarga hanya pasien yang sakit seperti ini. Riwayat sosial: pasien selalu memasak memakai kayu api. Pemeriksaan fisik umum: tekanan darah 110/70 $\mathrm{mmHg}$ dan status generalis lainnya dalam batas normal. Status oftalmikus: visus okuli dekstra (VOD) 6/15 yang dapat dikoreksi dengan $\mathrm{C}+100 \mathrm{X} 105^{\circ}$ menjadi 6/9. Visus okuli sinistra (VOS) 6/6. Tekanan intraokuler (TIO) okuli dekstra et sinistra 14,6 mmHg. Pada okuli dekstra terdapat tumor berkonsistensi lunak, permukaan 'berbukit-bukit', berwarna hitam kecoklatan, juga terdapat pembuluh-pembuluh darah. Lokasi tumor di daerah lateral limbus meluas masuk ke kornea dan melebar ke konjungtiva bulbi superior dan inferior. Gerakan bola mata masih dalam batas normal ke segala arah, kecuali ke temporal kanan agak terhalang karena adanya tumor. Lapangan pandang terbatas di daerah lateral 
kanan, refleks pupil (+) isokor, tes color vision normal, Amsler grid normal, Relative Afferent Papillary Defect/RAPD (-), kornea jernih, kecuali di sekitar tumbuhnya tumor kornea agak keruh, iris sinekia (-), dan lensa jernih. Segmen anterior okuli sinistra dalam batas normal. Funduskopi ODS: papil nervus optikus, retina dan makula dalam batas normal. Laboratorium darah rutin, fungsi hati, ginjal, profil lipid, clotting time dan bleeding time dalam batas normal. Pemeriksaan EKG dalam batas normal dan pada $\mathrm{X}$-foto toraks tidak terdapat metastase.

Diagnosis yang ditegakkan adalah melanoma konjungtiva disertai astigmatisma hipermetropikus simpleks okuli dekstra dan presbiopia. Terapi sementara diberikan artificial tears (Lyteers) tetes mata $3 \times 1$ tetes pada okuli dekstra. Direncanakan untuk melakukan eksisi total dan pemeriksaan histopatologi; bila hasilnya suatu proses keganasan, akan dilakukan eksenterasio bulbi dekstra. Prognosis adalah dubia ad malam.

\section{BAHASAN}

Kasus melanoma konjungtiva merupakan kasus yang jarang terjadi pada wanita. Laporan dari Swedia mengemukakan insidens melanoma konjungtiva ditemukan terbanyak pada pria $(0,74 \%)$ per satu juta penduduk sedangkan wanita hanya $0,54 \%$ per satu juta penduduk. ${ }^{8}$

Secara teoritis, penyebab melanoma maligna berasal dari primary acquired melanosis, dari nevus yang sudah ada sebelumnya, atau sebagai lesi de novo. ${ }^{8-11}$ Diagnosis ditegakkan mulai dari anamnesis sampai pemeriksaan klinik. Dari anamnesis diperoleh bahwa asal tumor dari nevus yang sudah ada sebelumnya, dimana nevus ini timbul sejak usia masih remaja (belasan tahun). Kemungkinan bertumbuhnya tumor karena mata pasien selalu terpapar dengan asap kayu api, dan diduga mekanismenya sama dengan faktor tumbuh ulang pada pterigium.

Mengenai asal perkembangan melanoma konjungtiva dikemukakan beberapa kemungkinan: ${ }^{8-11}$

\section{Primary acquired melanosis (PAM)}

Sekitar 50-75\% kasus melanoma konjungtiva berawal dari PAM. Biasanya kelainan ini ditemukan pada orang kulit putih usia pertengahan, dan jarang pada usia muda. PAM diawali berkembangnya pigmentasi epitel superfisial, dengan distribusi tipikal dari pigmen. Lesi tumbuh perlahan-lahan selama bertahun-tahun, meluas secara radial di daerah konjungtiva dan kulit.

\section{Nevus}

Sekitar $20-25 \%$ pasien melanoma konjungtiva memiliki riwayat atau dengan mikroskopik terbukti berasal dari nevus jinak. Pada pasien ini, lesi (nevus) telah ada sejak usia remaja di pinggir lateral limbus okuli dekstra, kemudian makin meluas ke superior dan inferior pinggir limbus, dan sejak enam bulan terakhir baru menonjol di permukaan bulbi. Melanoma maligna yang timbul dari nevus biasanya memperlihatkan berbagai perubahan, seperti nodularitas meningkat, pigmentasi beraneka ragam, perdarahan, atau peradangan.

\section{De novo (tanpa riwayat histologik atau bukti klinis bahwa lesi telah ada)}

Sekitar 25\% kasus melanoma konjungtiva berasal dari lesi de novo. Lesi ini bisa bersifat ulseratif, amelanotik, papillary, atau seperti jamur.

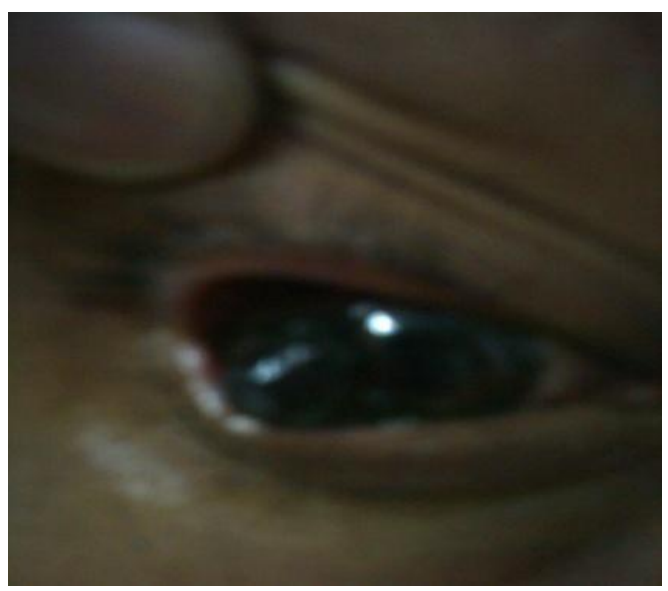

Gambar 1. Foto mata kanan pasien 


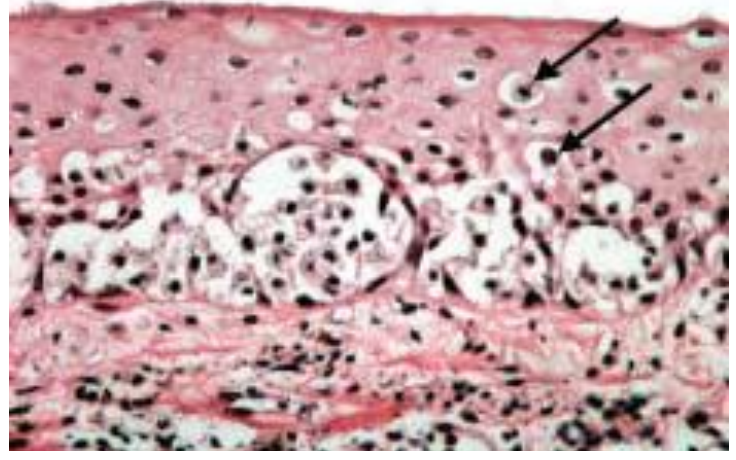

Gambar 2. Gambaran histopatologik PAM dengan atipia

Menurut klasifikasi secara klinis (cTNM) maka pasien dengan tumor ini tergolong dalam stadium T2N0M0 dimana tumor berlokasi pada konjungtiva bulbi lebih dari satu kuadran, belum terdapat metastase di kelenjar limf regional dan tidak ada metastase jauh. ${ }^{12}$

Penatalaksanaan melanoma konjungtiva yang utama adalah pembedahan. Terapi konservatif pilihan adalah topikal mitomicin-C sebagai kemoterapi, dan dilakukan pada melanoma konjungtiva PAM dengan atipia (Gambar 2). Bila tumor berada di daerah limbus konjungtiva bulbi tindakan awal diberikan alcohol epitheliectomy yang diikuti dengan eksisi lokal luas (sampai 2-3 $\mathrm{mm}$ zona tenang) dengan tehnik partial lamellar scleroconjunctivectomy. Setelah eksisi secara luas, dapat ditambahkan dengan cryotherapy freeze-thaw disekitar konjungtiva. Hal ini dilakukan pada seluruh lesi karena sisa tumor pada daerah yang tidak diobati dapat menyebar melalui kelenjar getah bening lokal. Bila tumor besar atau telah menginvasi ke seluruh orbita maka tindakan yang dilakukan adalah eksenterasio bulbi, walaupun tidak dapat memperbaiki prognosis.

\section{SIMPULAN}

Telah dilaporkan kasus melanoma konjungtiva yang jarang ditemukan pada seorang wanita suku Kotamobagu berusia 42 tahun. Melanoma konjungtiva disini tumbuh dari nevus konjungtiva. Menurut klasifikasi secara klinis (cTNM) maka tumor pada kasus ini tergolong stadium T2NOM0 atas dasar tumor berlokasi pada konjungtiva bulbi lebih dari satu kuadran, belum terdapat metastase di kelenjar limf regional dan tidak ada metastase jauh. Direncanakan untuk melakukan eksisi total dan pemeriksaan histopatologik; bila hasilnya menunjukkan suatu keganasan maka akan dilakukan eksentrasio bulbi.

\section{DAFTAR PUSTAKA}

1. Seregard S. Conjunctival melanoma. Surv Ophthalmol. 1998;42: 321-50.

2. Jakobiec FA. Conjunctival melanoma. Arch Ophthalmol. 1980;98:1378-84.

3. Yu GP, Hu DN, McCormick S, Finger PT. Conjunctival melanoma: is it increasing in the United States?. Am J Ophthalmol. 2003;135:800-806.

4. Tuomaala S, Kivela T. Conjunctival melanoma: is it increasing in the United States? Am J Ophthalmol. 2003;136: 1189-90.

5. Paridaens AD, Minassian DC, McCartney AC, Hungerford JL. Prognostic factors in primary malignant melanoma of the conjunctiva: a clinicopathological study of 256 cases. Br J Ophthalmol. 1994;78:252-59.

6. McDonnell JM, Carpenter JD, Jacobs P, Wan WL, Gilmore JE. Conjunctival melanocytic lesions in children. Ophthalmology. 1989;96:986-93.

7. Stratus BA. Conjunctival melanoma: is it increasing in the United States? Am J Ophthalmol. 2003;136:1190.

8. Roque MR. Melanoma, conjunctival: overview [homepage on the internet] 2010. Nodate [cited 2010 Oct 25]. Available from: http://emedicine.meds cape.com/article/1191840-overview

9. Jakobiec FA, Rini FJ, Fraunfelder FT, Brownstein S. Cryotherapy for conjunctival primary acquired melanosis and malignant melanoma: experience with 62 cases. Ophthalmology. 1988;95: 1058-70.

10. Folberg R, Jakobiec FA, Bernardino VB. Benign conjunctival melanocytic lesions: clinicopathologic features. Ophthalmology. 1989; 96:36-461.

11. Roque MR. Melanoma, conjungtival: 
64 Jurnal Biomedik, Volume 3, Nomor 1, Maret 2011, hlm. 60-64

treatment \& medication [homepage on the internet] 2010. Nodate [cited 2010 Oct 25]. Available from: http:// emedicine.medscape.com/article/119184 0 -treatment

12. Roque MR. Melanoma, conjungtival: differential diagnoses \& workup [homepage on the internet] 2010. Nodate [cited 2010 Oct 25]. Available from: http://emedicine.medscape.com/ article/1191840-diagnosis 